\section{Commentary: Strength, flexibility, and resilience are the keys}

\author{
Jennifer S. Lawton, MD
}

Gemmato and Baldwin ${ }^{1}$ discuss the challenges of being both cardiac surgeons and parents and highlight the barriers encountered by women cardiac surgeons. They openly detail their experiences and struggles and suggest areas in need of change in our specialty. I comment on their manuscript from the perspective of a cardiac surgeon married to another surgeon (an otolaryngologist) with 2 children.

Dual-surgeon relationships in our field will become more common as more women become cardiothoracic surgeons, although in 2016 estimates were that only $5 \%$ of cardiothoracic surgeons were women $(3 \%$ of adult cardiac, $5 \%$ of congenital, and $8 \%$ of thoracic surgeons). ${ }^{2,3}$ Other notable surgeon combinations that I have had the privilege of knowing include Dr Alec Patterson (thoracic surgeon, Professor of Surgery, former Chief of Division of Cardiothoracic Surgery, and 90th President of the American Association for Thoracic Surgery, and editor of the Annals of Thoracic Surgery) and his wife Dr Susan Mackinnon (plastic surgeon, Professor of Surgery, Chief of Division of Plastic and Reconstructive Surgery, and President of American Association of Plastic Surgeons) and Dr Jennifer Romano (congenital heart surgeon, Associate Professor of Surgery) and her husband Dr Matthew Romano (adult cardiac surgeon, Associate Professor of Surgery). Both couples also have children. Facing the unique challenges of a 2surgeon family, I have learned that strength (support of one another and persistence despite adversity), flexibility (accept emergent changes), and resiliency (the ability to improvise and make a bad situation better) have helped navigate our unique lives.

Dual-physician relationships are more common among female surgeons compared with male surgeons. ${ }^{4}$ In a survey

\footnotetext{
From the Division of Cardiac Surgery, Department of Surgery, Johns Hopkins University, Baltimore, Md.

Disclosures: The author reported no conflicts of interest.

The Journal policy requires editors and reviewers to disclose conflicts of interest and to decline handling or reviewing manuscripts for which they may have a conflict of interest. The editors and reviewers of this article have no conflicts of interest.

Received for publication Oct 12, 2020; revisions received Oct 12, 2020; accepted for publication Oct 15, 2020; available ahead of print Oct 20, 2020.

Address for reprints: Jennifer S. Lawton, MD, Johns Hopkins Hospital, 1800 Orleans St, Zayed 7107, Baltimore, MD 21287 (E-mail: jlawton4@jhmi.edu).

J Thorac Cardiovasc Surg 2022;163:184-5

0022-5223/\$36.00

Copyright (c) 2020 by The American Association for Thoracic Surgery

https://doi.org/10.1016/j.jtcvs.2020.10.046
}

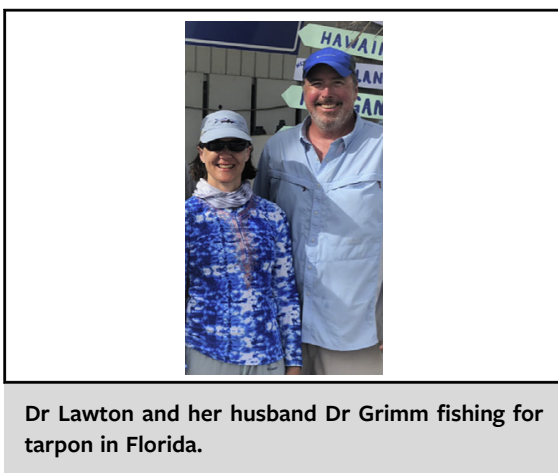

CENTRAL MESSAGE

A career in cardiothoracic surgery is challenging and rewarding, and things become much more complicated when 2 surgeon partners become parents.

of American College of Surgeons members (335 surgeon + surgeon and 830 surgeon + nonsurgeon physicians), more surgeons partnered with other surgeons noted work-home conflict, greater mean emotional exhaustion scores, and that raising children slowed their career advancement compared with surgeons with nonsurgeon physicians; however, burnout and satisfaction with their time for personal and family life were not different between the 2 groups. ${ }^{5}$ Some of the pros and cons of 2-surgeon relationships are listed in Table 1.,6,7

Gemmato and Baldwin also emphasize the fact that female and male surgeons are treated differently. ${ }^{1,8-10}$ After 20 years in practice, I am still mistaken for the nurse by patients and staff, and I have been mistaken for the spouse or the industry representative, and not the surgeon, when traveling with my husband to my own cardiothoracic meetings. Referral patterns to female surgeons have been shown to be reduced following a bad outcome, whereas the same is not true for male surgeons. ${ }^{11}$ Gemmato and Baldwin note lower salary offers to the more senior Gemmato compared with Balwin. ${ }^{1} \mathrm{Un}$ fortunately, inequity in compensation in surgical subspecialties has been noted to be roughly $\$ 44,000$ less for women than to that of comparable men. ${ }^{12}$

Despite these challenges, women need to be encouraged to enter our field. Unfortunately, in a recent survey of American College of Surgeons members, cardiothoracic surgery 
TABLE 1. Pros and cons of surgeon relationships

\begin{tabular}{ll} 
Pros & Cons \\
Unique level of understanding & Life is unpredictable, "organized \\
that can only be shared & chaos" \\
with a fellow surgeon, ${ }^{1}$ ie, & Career moves are challenging- \\
"Good luck, that sounds & whose job is more important? \\
like a hard case" instead of & Call schedules \\
"I can't believe you are & Academic productivity may \\
going to miss dinner again" & suffer \\
Dual-income support for & Guilt (never a good surgeon or \\
domestic help & parent) \\
& Greater risk of infertility ${ }^{7}$ \\
\hline
\end{tabular}

was the lowest specialty ranked when members were asked which specialty would be the most receptive to women when advising women or men on a career choice. ${ }^{13}$ In addition, $57 \%$ of cardiothoracic surgeons would advise only men to pursue a career in cardiothoracic surgery ${ }^{13}$ ! Fortunately, Gemmato and Baldwin will be their own prospective trial as they progress through their careers in terms of salary offerings, speed of academic promotion, and practice referrals, etc. Hopefully, they will share these experiences to educate us on our implicit biases so that we may combat them.

Cardiothoracic surgery is a tremendously rewarding and satisfying career. To provide a more diverse workforce, we need to embrace and encourage life outside the hospital, model this behavior to our students and residents, and mitigate implicit bias for the future generation. We must tell them that with strength, flexibility, and resilience, you CAN have it all!

\section{References}

1. Gemmato CJ, Baldwin ACW. Yes, we are both cardiac surgeons: one family's unique perspective on work-life balance. J Thorac Cardiovasc Surg. 2022;163: 179-83.

2. Stephens EH, Robich MP, Walters DM, DeNino WF, Aftab M, Tchantchaleishvili V, et al. Gender and cardiothoracic surgery training: specialty interests, satisfaction, and career pathways. Ann Thorac Surg. 2016;102:200-6.

3. Shemin RJ, Ikonomidis JS. Thoracic surgery workforce: report of STS/AATS thoracic surgery practice and access task force-snapshot 2010. Ann Thorac Surg. 2012;93:348-55. 355.e1-6.

4. Dyrbye LN, Shanafelt TD, Balch CM, Satele D, Sloan J, Freischlag J. Relationship between work-home conflicts and burnout among American surgeons: a comparison by sex. Arch Surg. 2011;146:211-7.

5. Dyrbye LN, Shanafelt TD, Balch CM, Satele D, Freischlag J. Physicians married or partnered to physicians: a comparative study in the American College of Surgeons. J Am Coll Surg. 2010;211:663-71.

6. Lawton JS. Organized Chaos. CTSNet.org; 2009. Available at: www.ctsnet.org/ article/organized-chaos. Accessed October 12, 2020.

7. Cheesborough JE, Gray SS, Bajaj AK. Striking a better integration of work and life: challenges and solutions. Plast Reconstr Surg. 2017;139:495-500.

8. Cochran A, Hauschild T, Elder WB, Neumayer LA, Brasel KJ, Crandall ML. Perceived gender-based barriers to careers in academic surgery. Am J Surg. 2013;206:263-8

9. Schroen AT, Brownstein MR, Sheldon GF. Women in academic general surgery. Acad Med. 2004;79:310-8.

10. Carr PL, Ash AS, Friedman RH, Szalacha L, Barnett RC, Palepu A, et al. Faculty perceptions of gender discrimination and sexual harassment in academic medicine. Ann Intern Med. 2000;132:889-96.

11. Sarsons H. Interpreting Signals in the Labor Market: Evidence from Medical Referrals. Available at: https://scholar.harvard.edu/sarsons/publications/interpretingsignals-evidence-medical-referrals. Accessed October 12, 2020.

12. Jena AB, Olenski AR, Blumenthal DM. Sex differences in physician salary in US public medical schools. JAMA Intern Med. 2016;176:1294-304.

13. Altieri MS, Price KL, Yang J, Jones DB, Pryor AD. What are women being advised by mentors when applying to surgery? Am Surg. 2020;86:266-72. 